Golden Age: Jurnal Pendidikan Anak Usia Dini, Volume 4 Nomor 1 (Juni 2020)

ISSN 2549-8371 | E-ISSN 2580-5843

Nandang Rukanda/ Efforts to Stimulate Entrepreneurship Character for Early Childhood through Innovative Learning Methods Based on Science, Technology, Engineering, Art, and Math (STEAM)

\title{
Efforts to Stimulate Entrepreneurship Character for Early Childhood through Innovative Learning Methods Based on Science, Technology, Engineering, Art, and Math (STEAM)
}

\author{
NANDANG RUKANDA \\ Pascasarjana Pendidikan Masyarakat, IKIP Slliwangi, Bandung, Indonesia. \\ Email: nandangsae@gmail.com
}

Article Received: 21 November 2019

Published Article: 01 Juni 2020

DOI: https://doi.org/10.29313/ga:jpaud.v4i1.5369

\begin{abstract}
This study aims to examine innovative learning methods based on Science, Technology, Engineering, Art, and Math (STEAM) to stimulate the formation of mental entrepreneurship for young children so that they become independent entrepreneurs in the future. This study uses several theoretical studies used as a basis, namely the theory of out of school education, critical pedagogy, and entrepreneurship. The writer uses the qualitative approach with the case study method as a research approach. The results showed that the application of STEAM learning methods in early childhood students could stimulate their entrepreneurial spirit for their future.
\end{abstract}

Keywords: Out-of-School Education; Critical Pedagogy; Entrepreneurship.

\begin{abstract}
Abstrak
Penelitian ini bertujuan untuk mengkaji metode pembelajaran inovatif berbasis Science, Technology, Enginering, Art, dan Math (STEAM) dalam rangka menstimulasi pembentukan mental entrepeneur bagi anak usia dini supaya di masa depan menjadi wirausaha mandiri. Penelitian ini menggunakan beberapa kajian teoretis yang dijadikan landasan, yakni teori pendidikan luar sekolah, pedagogi kritis, dan kewirausahaan. Pendekatan kualitatif dengan metode studi kasus digunakan penulis sebagai pendekatan penelitian. Hasil penelitian memperlihatkan bahwa penerapan metode pembelajaran STEAM pada peserta didik anak usia dini dapat menstimulasi pembentukan jiwa wirausaha mereka untuk untuk masa depannya.
\end{abstract}

Kata Kunci: Pendidikan Luar Sekolah; Pedagogi Kritis; Kewirausahaan. 
Golden Age: Jurnal Pendidikan Anak Usia Dini, Volume 4 Nomor 1 (Juni 2020) ISSN 2549-8371 | E-ISSN 2580-5843

Nandang Rukanda/ Efforts to Stimulate Entrepreneurship Character for Early Childhood through Innovative Learning Methods Based on Science, Technology, Engineering, Art, and Math (STEAM)

\section{INTRODUCTION}

Early childhood is a unique individual who has patterns of growth and development in aspects of physical, cognitive, social, emotional, creativity, language, and communication specific to the stage being passed by the child.

Article 28 of the Law on National Education System No. 20/2003 Paragraph 1, including early childhood, is a child that falls within the age range of $0-6$ years. So, early childhood is a child that ranges between the ages of $0-6$ years who have extraordinary growth and development so that it appears various uniqueness in him. Early age is a developmental period that determines the development of the next period. Experts in various studies concluded that early childhood education could improve performance and increase adult work productivity.

Early childhood as the next generation of the nation is expected to have noble character and entrepreneurial character to become the next generation that is independent and globally competitive. In essence, early childhood is an asset, reserve, and hope of the nation in the future. History proves that there have been significant changes at the hands of the next generation. Therefore, early childhood is not enough if only directed to become workers, but it is very urgent to be formed into entrepreneurs who can advance themselves and their nation independently.

Early childhood needs to be prepared to have an entrepreneurial mentality to work independently in the future. The entrepreneurial spirit is a mentality to work to produce something that is measured in the form of material or money. The entrepreneurial spirit needs to be instilled since one starts to realize that money is necessary and that someone can deal with goods or services that can be sold. The cultivation of an entrepreneurial spirit from an early age requires that a person learns to be more independent, to think critically, and to advance because he will think about how to process the results of the skills or learning outcomes that he has been doing to become a work that can be sold.

The Indonesian nation is large, but the number of entrepreneurs in Indonesia is still minimal compared to its population. One of the reasons is the behavior of Indonesian people who are not encouraged to improve their entrepreneurial abilities so that they can live independently and productively. Early childhood as the next generation of the nation needs to be directed not only in intellectual abilities but also in entrepreneurship.
PAUD Bani Shelah is one of the PAUD Institutions based on religious children's development, especially to form students who have moral values. Therefore, this is in line with the theme of the problem to be examined.

The main objective of establishing Bani Shaleh early childhood education is to gather young children to be given essential debriefing in preschool education preparation and to face primary education in traditional schools that will come for their future lives.

Entrepreneurship is not only an adult's world but can also be part of a children's world. The difference is that children's entrepreneurship is the only stimulation that requires guidance and support from adults, parents, and teachers. Children who know the world of entrepreneurship from an early age will benefit from their future stock. At an early age, children who learn entrepreneurship will grow into creative personalities. The creativity that is trained from an early age through various entrepreneurial activities becomes the principal capital of children's productivity and independence as adults.

PAUD Bani Shaleh seeks to instill an entrepreneurial spirit through learning programs run on students in an innovative way based on the Science, Technology, Engineering, Art, and Math (STEAM) models.

\section{LITERATURE REVIEW}

\section{A. The character of Entrepreneurship in Early Childhood}

\section{Concept of Entrepreneurship}

Entrepreneurship is a human process that is related to creativity and innovation in understanding opportunities, organizing, and managing resources so that opportunities are realized into a business that can generate profits or value for an extended period. The definition focuses on aspects of creativity and innovation. Because with creative and innovative, someone can find opportunities

The concept of entrepreneurship is also called entrepreneurship, which has a broad meaning. One of them, the entrepreneur, has a high ability to make changes and has very few characteristics found in a population. Another definition, entrepreneurship is someone who wants to work for himself.

Entrepreneurship talks have long been discoursing in Indonesia, both at the formal level in 
Nandang Rukanda/ Efforts to Stimulate Entrepreneurship Character for Early Childhood through Innovative Learning Methods Based on Science, Technology, Engineering, Art, and Math (STEAM)

universities and government and at the informal level in the community's economic life.

Previously, people assumed that entrepreneurship is only an innate talent (entrepreneurship are born nat made) and is only obtained from practice at the field level and cannot be learned and taught. However, entrepreneurship is now a discipline that can be learned and taught.

The science of entrepreneurship is a discipline that studies the values, abilities (ability), and behavior of a person who is facing life challenges to obtain opportunities with various risks that may be faced (Suryana, 2001).

In essence, entrepreneurship is the nature, characteristics, character, and spirit of someone who has the will to realize innovative ideas into the real world creatively.

\section{Characteristics of Entrepreneurship}

An entrepreneur is a person who has an entrepreneurial spirit and applies the nature of entrepreneurship in his life. Also, an entrepreneur includes people who have high creativity and innovation in his life.

A common characteristic inherent in an entrepreneur is changing things for the better or creating something genuinely new, or having a creative and innovative spirit. That way, these creative and innovative traits are inherent in an entrepreneur.

Entrepreneurship is the ability to create something new and different. Entrepreneurship is also called a process of applying creativity and innovation to solve problems and find opportunities to improve life (business).

This understanding implies that an entrepreneur is a person who can create something new and different from the others. That means he can create something different from what was before.

Based on experts' views, it can be concluded that entrepreneurship is an ability in creative thinking and innovative behavior that is used as a basis, resources, driving force, tactics, tips, and processes in facing life's challenges. Creativity is thinking about something new, whereas innovation is the act of doing something new.

Meredith et.a (Suryana, 2001, p. 8) provide

the characteristics and character of entrepreneurship.

a. Confidence and confidence are independent, individual, and optimistic;

b. Task and results-oriented is the need for achievement, profit-oriented, perseverance, determination, determination, hard work, strong drive, energetic, and initiative;

c. Risk-taking is the ability to take risks that are reasonable and like challenges;

d. Leadership is behavior as a leader, associating with others, and responding to suggestions and criticisms;

e. Original, innovative, creative, and flexible, and

f. Future-oriented.

\section{The character of Entrepreneurship in Early Childhood}

Family, community and educational institutions are essential elements that influence and shape the character of entrepreneurs. A child's character is formed through what is heard, what is seen, and what is felt. Hearing and sight are the entrance of learning before entering into conscience. Through all the senses that humans have, healthy learning will emerge from what is received by the senses (PFIPUN, 2017 (Nurhafizah, 2018, p. 63)). Fitri et al. (in (Fitri, Zola, \& Ifdil, 2018), revealed that if children are accustomed to and confident in the entrepreneurial world since childhood, then this character will emerge later when an adult child (compare Nurhafizah, 2010; Nurhafizah, 2011).

Entrepreneurship learning in early childhood can be applied in an integrated manner with other educational activities in schools. The implementation of entrepreneurship education must be carried out by the principal, teachers, and students together as an educational community. Entrepreneurship education is realized into a hidden curriculum (hidden curriculum) by identifying the types of activities in schools that can realize entrepreneurship education in daily life.

\section{B. Early Childhood Learning}

\section{Concepts of Learning in Early Childhood}

The Law on the National Education System states that early childhood education is a coaching effort aimed at children from birth until the age of six carried out through the provision of educational stimuli to help physical and spiritual growth and development so that children have the readiness to enter more education continued (see Law Number 20 the Year 2003 Chapter I Article 1 Paragraph 14).

According to Sujiono and Sujiono (in (Sujiono, 2009, p. 138)), learning activities in early childhood are concrete curriculum development in the form of a set of plans containing several learning experiences through play given to early childhood 
Nandang Rukanda/ Efforts to Stimulate Entrepreneurship Character for Early Childhood through Innovative Learning Methods Based on Science, Technology, Engineering, Art, and Math (STEAM)

based on the potential and developmental tasks that are must be mastered to achieve the competencies that must be possessed by children.

Based on the above opinion, it can be stated that learning for early childhood has several characteristics, namely: (1) Learning, playing, and singing. Early childhood learning uses the principles of learning, playing, and singing (Suyanto, 2005, p. 133). Learning for young children is realized so that it can make children active, happy, and free to choose. Children learn through interaction using play equipment and equipment, as well as humans. Children learn by playing in a pleasant atmosphere. Children's learning outcomes would be better if learning activities are carried out with peers. In learning, children tend to use all the senses; and (2) Development-oriented learning. Developmentoriented learning refers to three essential things, namely 1) oriented at the right age, 2) oriented to the right individual, and 3 ) oriented to the socio-cultural context (Masitoh, 2005, p. 3.12).

\section{Critical Pedagogy}

Pedagogy comes from Ancient Greek, which consists of two words, namely pais, which means child '(child) and agi, which means' lead '(lead). So, pedagogy means to lead the child or 'lead the child.' In its development, pedagogy is often interpreted as education/science to educate minors. Nevertheless, the term pedagogy is often intended as education in a general/broad sense (education) without differentiating the level of maturity of a child's age.

Critical pedagogy is a learning approach that seeks to help students question and challenge the dominance and belief of the practices that dominate it (Wikipedia). Furthermore, critical pedagogy can be interpreted as critical education. That means education always questions and criticizes education itself in fundamental matters about education, both at the philosophical level, theory, system, policy, and implementation.

In the level of education/learning practices, several important concepts are part of critical pedagogy, including constructivism, banking concepts of education, problem-posing education, and dialogical methods. These concepts are related to all critical pedagogy dimensions, but their implementation can occur even though they refer to pragmatic, practical interests without relating them to political ideology dimensions. As a result, the implementation can be seen as a part that absorbs critical pedagogy, both because of ideological awareness and awareness of the importance of improving the quality of education to face the challenges of rapid change.

Critical pedagogy is precisely implemented in teaching early childhood today because of its flexibility and without emphasis so that it makes the early childhood learners free to express and explore all their potentials and thoughts.

\section{Innovative Learning Methods Based on Science, Technology, Engineering, Art, and Math (STEAM)}

Activities undertaken by children in PAUD with their teachers and peers can be maximized by instilling the mindset to become an entrepreneur (entrepreneur). The things that teachers can do are provide facilities, creative teaching methods and link what is taught with thinking like an entrepreneur. Later, when they grow up, children will get used to entrepreneurial activities, and most importantly, children will not be afraid to take a risk. School activities related to entrepreneurship are balancing for children to apply what children get from the teacher's lessons. An example is when there is a theme of "plants", the teacher can teach how to plant plants and care for them to use plants.

Entrepreneurship learning for children needs to be fostered early on, not only at the level of mental formation but also by telling children about the entrepreneurial definition and how it benefits and how. However, entrepreneurship can be integrated into a learning theme through a hidden curriculum. Things like this can be done creatively by the teacher when giving material. (Primitia Yogi, 2011 (Nurhafizah, 2018, p. 64)).

Learning approaches that provide freedom of learning for children with innovative learning methods based on STEAM will make the experience directly to children to interact with the surrounding environment, the people around them, playing tools, even with their ideas. Children must be given the freedom to choose the activities they like. That way, children's knowledge will be developed through interaction with the surrounding environment and their people.

STEAM learning methods are very suitable for raising children during the increasingly massive digital era. The ease of getting information from all sources and the technological sophistication that has increasingly made children dependent. This is not an easy matter. Parents inevitably have to be sensitive to the changing times and follow technological developments to guide them to use technology wisely and appropriately. 
Golden Age: Jurnal Pendidikan Anak Usia Dini, Volume 4 Nomor 1 (Juni 2020) ISSN 2549-8371 | E-ISSN 2580-5843

Nandang Rukanda/ Efforts to Stimulate Entrepreneurship Character for Early Childhood through Innovative Learning Methods Based on Science, Technology, Engineering, Art, and Math (STEAM)

In educating, parents can encourage their children to explore, create, and find new ways to solve problems. It is useful to form problem-solving skills in children from an early age. STEAM can hone the communication skills and critical thinking power of children.

\section{RESEARCH METHODS}

In this research, the approach taken is quantitative. It is intended to reveal social phenomena that do not prioritize the numbers but about humanitarian motivation and behavior that measure the depth of study's depth.

According to (Moleong, 2005, p. 6), qualitative research is research that intends to understand phenomena about what is experienced by research subjects, for example, behavior, perception, motivation, actions, etc. holistically and using descriptions in the form of words and language in a special natural context and by utilizing natural methods.

Underlying this research is motivation, which influences one's entrepreneurial behavior. Therefore, a research design is prepared to reveal social phenomena in-depth and comprehensively with research designs that provide opportunities for development during the research process.

Population or population, according to language, means the population or the public are expected. In this study, Engking Soewarman Hasan in his book (Hasan, 1997, p. 54) asserted that the intended population is the entire object of research, possibly in the form of humans, symptoms of attitude patterns, behavior, and so on which are the research of the objects.

The population is a generalization area consisting of objects/subjects with specific characteristics determined and then conclude. So, the population is not just people, but also other natural objects. The population is also not just the number of objects/subjects studied but includes all the subject or object's characteristics/properties (Sugiyono, 1999, p. 57).

A population is a group of subjects that will be the source of data, both in objects, humans, symptoms, and events by the subject matter under study. Another definition considered simpler was Suharsimi Arikunto in his book (Arikunto, 1987, p. 102), namely the population is the whole object under study.

Based on the theories and concepts above, this study establishes the study population, namely the personnel involved in the activities of organizing teaching and learning in PKBM Suka Baru, Cigugur Girang Village.

The sample is part or representative of a population that has the same characteristics/traits and can represent the population. Experts do not provide certainty about how large a sample should be taken from a qualitative study. However, in general, experts provide estimates to determine the sample size of a population.

In this study, the authors used a purposive sampling technique as sampling. With this technique, researchers take samples by setting traits by the objectives to be achieved. Sugiyono in (Sugiyono, 2011, p. 84) states that purposive sampling is a sampling technique with certain considerations.

In this study, the sample used by researchers is the personnel involved in organizing teaching and learning activities at PKBM Suka Baru, Cigugur Girang Village.

The following are the steps or procedures carried out in this study. In this planning, researchers prepare data collection tools in advance, namely in the form of a grid systematically by the problem or research question. The following are activities in the preparation of data collection tools: (1) Formulating research problems with appropriate variables and indicators to be used as research questions; (2) Arranging questions along with alternative answers that are adjusted to the research problem and accompanied by instructions to fill in so that it will be clear what is intended and addressed by the respondent.

Actions, researchers divide the role of respondents, then researchers provide treatment with observation and interviews to reveal opinions and actual conditions: data analysis, formulation of study results, the arrangement of recommendations for decision making.

In research, needed data or information that is useful for problem-solving material analyzed. For this reason, appropriate data collection techniques are needed. The aim is that this research reaches the desired target.

The data collection techniques used in this study are: (1) Observation is a direct review of the object of research, such as a description of the area of the research location and extension activities; (2) Interview is an activity to get data in answer to the research questions themselves; (3) Literature Study is a reference of supporting material in a theoretical description that if it has to do with counseling and is also used as an adjunct technique in data collection.

Data analysis in this research was carried out inductively. The point is that research is done by 
not starting from the deduction of theory but starting from empirical facts. The study continued with a direct foray into the field to study, analyze, interpret, and draw conclusions from phenomena in the field. Researchers are faced with factual data obtained from the field. After that, the researcher analyzed the data so that it is found the meaning, which then becomes the result of the research.

Qualitative analysis was conducted by researchers throughout the study from beginning to end. This is intended because qualitative research requires data that requires analysis from the beginning of the study. The results of the initial analysis will determine the next research process.

The research stages are carried out mainly at the stage of reduction and presentation of data, but it does not always occur hand in hand. After the data is presented, sometimes data reductions are also needed before a conclusion is drawn.

\section{DISCUSSION}

STEAM is known as an applied learning method that requires an interfaith approach. The application is usually accompanied by active and problem-based learning.

To produce an interactive and fun atmosphere of teaching and learning in PAUD Bani Shaleh, STEAM is implemented by designing a special classroom. The trick is not to arrange chairs and tables in a row and rigid, but chairs and tables can be moved flexibly according to student learning needs.

Flexibility will also be reflected by placing a blackboard that is not glued to one side of the room. As a result, teachers and students can freely express their creative ideas on blackboards that are scattered in various corners of the room. Also, classroom walls must be designed as attractive as possible with a variety of colors that are tailored to the age of the students. The aim is to maximize children's creativity.

Educators can carry out entrepreneurial learning activities in several ways, namely 1) by providing several activities that can be followed by students according to their needs, potential, talents, and interests; 2) by organizing activities that provide opportunities for students to express themselves freely through independent or group activities.

The learning method used includes entrepreneurial activities actively, creatively, and innovatively in the learning material provided by educators. How to do this is 1) Children are invited to plant crops with simple plants; children grow, care, to harvest themselves. In time, the child will sell the crops to the parents who come. Then, the money from the sale is saved from being class cash, and each child has a record of the amount of money he makes. 2) Students are invited to visit places of entrepreneurship activities while working on tours, such as to cattle ranching, to the place of making regional specialties, and others. Later, the children will see every process of the activity. 3) Children can also be invited to visit shopping places, such as traditional markets and supermarkets.

However, children are first provided with a teacher with sufficient money and notes to buy. That way, children will learn to count, pay, and even receive change. In this activity, the teacher's role is only as a supervisor and motivator.

Planning and implementing entrepreneurship education can be done by integrating into daily activities at school, for example, "Family Day" activities (children sell their work), and parents must be directly involved in the entrepreneurial activities (entrepreneurs). In making the "Family Day" program, fathers and mothers are involved in school activities, including performing, performances made by children, and various foods that children have tried in cooking programs. Parents are expected to ask questions about the manufacturing process so that the focus of this activity is on children being able to explain to adults how the work they have made. Also, this activity teaches that what they have made can produce work and money. In this case, parents are also asked to be obliged to buy children's work, and all proceeds from the sale are saved as cash for their class.

Critical analysis of education is so important and an effort to continue developing the critical pedagogy movement. This is in line with Henry Giroux's idea of offering a "knife" to criticize oldfashioned, outdated views. He also formulated a new view of humans about the social environment. Also, he encouraged people to be involved in the process of forming a just and prosperous democratic society.

Because it involves an effort to free human and physical life, freedom becomes one of the critical issues in education. The point is that people are more aware of their obligations and rights as part of society. Thus, man is no longer dependent on others, and he can rely on his strength.

\section{CONCLUSION}

Because it lasts throughout civilization and along with the changing times, education is essential for humans. It is related to human efforts to liberate 
Nandang Rukanda/ Efforts to Stimulate Entrepreneurship Character for Early Childhood through Innovative Learning Methods Based on Science, Technology, Engineering, Art, and Math (STEAM)

the mind and its birth so that humans do not have to depend on others but he can rely on his strength.

Parents' role in forming an entrepreneurial spirit is essential through various means, such as dialogue or good discussion with role models. Children are taught and given examples, how to take advantage of available opportunities, both time opportunities, goods opportunities, service opportunities, money opportunities, skills opportunities, intelligence opportunities, friendship opportunities, cooperation opportunities, and trust opportunities.

Early Childhood Education Institutions become a place for children to gain knowledge and experience from educators' words, behavior, and exemplary attitudes. Educators should encourage children to explore, create, and find new ways to solve problems. The aim is to form a problem-solving skill in children from an early age.

Critical pedagogy with innovative learning methods based on science, technology, engineering, art, and math (STEAM) is very well used to hone children's communication skills and critical thinking power.

\section{REFERENCES}

Arikunto, S. (1987). Prosedur Penelitian: Suatu Pendekatan Praktik. Jakarta: Bina Aksara.

Fitri, E., Zola, N., \& Ifdil, I. (2018). Profil Kepercayaan Diri Remaja serta Faktor-Faktor yang Mempengaruhi. JPPI (Jurnal Penelitian Pendidikan Indonesia), 4(1), 1-5. https://doi.org/10.29210/02017182

Hasan, E. S. (1997). Metodelogi Penelitian PLS. Bandung: FIP IKIP.

Masitoh. (2005). Strategi Pembelajaran TK. Jakarta: Penerbit Universitas Terbuka.

Moleong, L. J. (2005). Metodologi Penelitian Kualitatif. Bandung: Remaja Rosda Karya.

Nurhafizah, N. (2018). Bimbingan Awal Kewirausahaan pada Anak Usia Dini. Jurnal Konseling dan Pendidikan, 6(2), 62-67. https://doi.org/10.29210/127300

Sugiyono. (1999). Metodologi Penelitian Administrasi. Bandung: Alfabeta.

Sugiyono. (2011). Metode Penelitian Kuantitatif, Kualitatif, dan R\&D. Bandung: Alfabeta.

Sujiono, Y. N. (2009). Konsep Dasar Pendidikan Anak Usia Dini. Jakarta: PT Macanan Jaya Cemerlang.
Suryana. (2001). Kewirausahaan. Jakarta: Penerbit Salemba Empat.

Suyanto, S. (2005). Konsep Dasar Anak Usia Dini. Jakarta: Departemen Pendidikan Nasional. 